\title{
PENGARUH PEER EDUCATION TERHADAP MINAT WUS MELAKUKAN IVA DI BANJAR TEGAL DESA KUBUTAMBAHAN KABUPATEN BULELENG
}

\section{THE EFFECT OF PEER EDUCATION TOWARD FERTIL AGED WOMEN'S INTEREST COMMITING IVA AT BANJAR TEGAL KUBUTAMBAHAN VILLAGE BULELENG REGENCY}

\author{
Ni Luh Gede Puspita Yanti1, I Ketut Yudha Sulantara2, \\ Silvia Ni Nyoman Sintari3
}

\begin{abstract}
ABSTRAK
Pendahuluan: Kesehatan reproduksi wanita yang menjadi pembunuh nomor dua saat ini setelah kanker payudara adalah kanker serviks. Deteksi dini diperlukan guna sebagai pencegahan sehingga dapat menekan angka kejadian kanker serviks, salah satunya dengan pemeriksaan IVA. Minat WUS untuk melakukan pemeriksaan IVA sebagai deteksi dini masih sangat rendah. Pendidikan teman sebaya (peer education) menjadi salah satu faktor untuk semakin meningkatkan minat WUS untuk melakukan deteksi dini kanker serviks. Tujuan penelitian ini untuk mengetahui pengaruh peer education terhadap minat WUS melakukan IVA di Banjar Tegal Desa Kubutambahan Kabupaten Buleleng. Metode : Penelitian pre eskperimental dengan rancangan penelitian yang digunakan adalah one group prepost test. Teknik sampling yang digunakan adalah Nonprobablity Sampling dengan Purposive Sampling didapatkan sampel dengan jumlah 44 orang. Hasil analisis univariat sebelum peer education didapatkan hasil minat WUS melakukan IVA pada kategori rendah sebanyak 24 orang (54,5\%) dan hasil analisis setelah peer education minat melakukan IVA pada kategori sedang sebanyak 33 orang (75\%). Hasil analisis menggunakan uji beda rata-rata Wilcoxon diperoleh nilai $p$ value 0,001 dimana nilai $\mathrm{p}<\alpha(0,05)$ yang artinya ada pengaruh peer education terhadap minat WUS melakukan IVA. Saran bagi WUS agar dapat menerapkan pemeriksaan IVA secara berkala dan dapat menyebarluaskan informasi yang didapat dari kegiatan peer education terkait kanker serviks dan pemeriksaan IVA kepada masyarakat.
\end{abstract}

Kata Kunci : Kanker serviks, IVA, Peer education, Minat

\begin{abstract}
ABSTRACK
Introduction: Woman reproduction health which nowadays becomes the second killer after breast cancer, is cervix cancer. It is needed early-detected prevention in order to reduce cervix cancer, one of them is IVA. The awareness of community as early-detected prevention is very low. Peer education becomes one of the factors to increase communities' awareness toward cervix cancer. This study aims at identifying the effect of peer education toward Fertile Aged Women's interest committing IVA in Banjar Tegal Desa Kubutambahan, Buleleng Regency. Method $:$ The pre experimental is conducted using one group pre-post test. Non probability and purposive sampling is used in sampling technic by involving 44 persons as
\end{abstract}


number of sampling. univariate result of community's interest committing before peer education is low, 24 persons (54.5\%) and community's interest after peer education are 33 persons (75\%). The study is analyzed by using Wilcoxon's average different test with $p$ value 0.001 which $p<\alpha(0.05)$. It means that there is effect of peer education toward community's interest in committing IVA. Suggestion to Fertil Aged Women's, in order to committing IVA frequently and spread information obtained from peer education related cervix cancer and IVA to societies.

Key words : Cervical Cancer, IVA, Peer education, Interests

\begin{tabular}{ll}
\hline Alamat Koresponden & : Jalan Kecak No 9A Gatot Subroto Timur Denpasar \\
Email & : wika_puspitayanti@yahoo.com \\
\hline
\end{tabular}

\section{PENDAHULUAN}

Masalah Indonesia serta dunia saat ini adalah adanya double burden yaitu masalah penyakit menular dan penyakit degeneratif. Penyakit degeneratif yang banyak terjadi pada wanita saat ini dan terus mengalami peningkatan adalah kasus kesehatan reproduksi. Kesehatan reproduksi wanita yang menjadi pembunuh nomor dua saat ini setelah kanker payudara adalah kanker serviks (Irianto, 2014). Kanker serviks merupakan suatu jenis kanker yang terjadi pada leher rahim yang disebabkan oleh Human Papilloma Virus (HPV).

Berdasarkan data American Cancer Society diperkirakan 527.600 kasus baru terjadi di seluruh dunia dengan angka kematian hampir 265.700 jiwa. Kematian akibat dari kanker serviks di berbagai negara hampir 90\% antara lain 60.100 kematian di Afrika, 28.600 kematian di Amerika Latin dan Carribean dan 144.400 kematian di Asia. India merupakan negara kedua dengan penyumbang kematian paling banyak akibat kanker serviks yaitu sebesar 25\% (American Cancer Society, 2017). Berdasarkan data riset kesehatan dasar (Riskesdas) prevalensi kanker di Indonesia adalah 1,4 per 1000 penduduk, sedangkan kanker serviks merupakan kanker dengan prevalensi kedua tertinggi di Indonesia sebesar 0,8\% atau sekitar 98.692 penduduk (Riskesdas, 2013).

Data dari surveilans terpadu penyakit di Provinsi Bali kasus baru kanker serviks pada tahun 2016 sebanyak 1.170 orang. Kanker serviks di Denpasar pada tahun 2016 terdapat 834 kasus baru kanker serviks dan 12 orang meninggal dunia, di Kabupaten Badung terdapat 238 kasus baru, di kabupaten Tabanan terdapat 46 kasus baru, di Kabupaten Bangli 26 kasus baru, di Kabupaten Buleleng 16 kasus baru dan 1 orang meninggal dunia, di Kabupaten Klungkung 6 kasus baru dan di Kabupaten Gianyar terdapat 4 kasus baru kanker serviks (Dinas Kesehatan Provinsi Bali, 2017).

Inspeksi visual asam asetat (IVA) menjadi salah satu pilihan yang digunakan oleh WUS untuk melakukan deteksi dini lesi pra kanker. Pemeriksaan metode IVA bisa dilakukan di Puskesmas atau di tempat praktik bidan swasta karena selain praktis dan murah metode ini memiliki sensivitas yang tinggi. IVA dapat mendeteksi lesi tingkat pra kanker dengan sensitivitas pada rentang 66\%-96\% dan spesifisitas 64\%-98\%, sedangkan nilai prediksi positif (positive predictive value) 
dan nilai prediksi (negative predictive value) masing-masing antara 10-20\% dan 92-97\% (Marliana, 2014).

Cakupan pemeriksaan IVA di Indonesia dari tahun 2008-2016 sebanyak 4,34\% dari total target 37,5\% (Kemenkes, 2016). Cakupan pemeriksaan IVA di Bali tahun 2015 menjadi provinsi paling tinggi dengan proporsi 18,45\% (Kemenkes, 2016a), namun jika dilihat cakupan data IVA di Buleleng masih jauh dari target nasional yaitu hanya sebesar 4,25\% dari 10\% target nasional (Dinas Kesehatan Provinsi Bali, 2015). Penyebab minimnya kunjungan ibu untuk melakukan pemeriksaan IVA karena beberapa faktor. Hasil penelitian yang membuktikan dan menemukan bahwa rendahnya pemeriksaan IVA terkait dengan tingkat pengetahuan yang rendah, sikap wanita yang masih memandang negatif pemeriksaan IVA (Dewi dkk, 2013), pendidikan rendah, status ekonomi yang kurang serta dukungan sosial (Dwika dkk, 2014) serta Paritas. Hal ini yang mengakibatkan perlu adanya suatu gerakan bersama untuk mencapai kesinambungan dan meningkatkan kepedulian masyarakat terhadap kanker serviks. Dukungan dari berbagai pihak menjadi salah satu pemicu munculnya minat WUS melaksanakan deteksi dini kanker servik. Pendidikan teman sebaya (peer education) menjadi salah satu faktor untuk semakin meningkatkan deteksi dini kanker serviks (Mbachu et.al, 2017).

Berdasarkan hasil studi pendahuluan yang dilakukan peneliti pada tanggal 20 Februari 2018 di Puskesmas Kubutambahan 1 selama tahun 2017 WUS yang melakukan pemeriksaan IVA di Desa Kubutambahan sebanyak 96 dari total WUS 2.303. Daerah yang berada di bawah wilayah kerja Puskesmas Kubutambahan 1 tercatat banjar yang paling sedikit melakukan pemeriksaan IVA selama tahun 2017 adalah banjar Tegal dengan jumlah 4 orang (2,5\%) dari 154 orang WUS. Hasil wawancara terhadap 3 orang WUS di Banjar Tegal didapatkan informasi bahwa para WUS tidak mau melakukan IVA karena kurang mendapatkan informasi mengenai pemeriksaan IVA dan rasa takut mengetahui penyakitnya jika terdeteksi.

\section{BAHAN DAN METODE}

Pada penelitian ini untuk mengetahui pengaruh peer education terhadap minat WUS melakukan IVA di Banjar Tegal Desa Kubutambahan Kabupaten Buleleng menggunakan desain one group pre-post test. Tempat penelitian ini dilakukan di Banjar Dinas Tegal, Desa Kubutambahan, Kabupaten Buleleng. Waktu penelitian ini dilaksanakan pada tanggal 19 April 2018 sampai tanggal 3 Mei 2018. Sampel dalam penelitian ini sebanyak 44 WUS yang diambil dengan teknik sampling Nonprobablity Sampling dengan Purposive Sampling yang memenuhi kriteria inklusi dan eksklusi. Penelitian ini terdiri atas dua variable, yaitu pemberian peer education sebagai variabel bebas dan minat WUS dalam melakukan pemeriksaan IVA sebagai variabel terikat.

Peneliti menetapkan peer educator sebelum intervensi diberikan. Peer educator diberikan materi terkait pelaksanaan IVA dan dievaluasi apakah peer educator sudah mampu menjadi leader dalam pendidikan teman sebaya (peer education). Pelaksanaan peer education dalam penelitian ini dilakukan selama tiga kali pertemuan selama dua minggu, materi yang diberikan terkait kanker serviks dan IVA dengan metode ceramah berupa satuan acara penyuluhan (SAP) dan diskusi. Penelitian ini menggunakan data primer yang diambil dari kuesioner yang diisi langsung oleh responden. Kuesioner yang dilakukan terdiri dari 20 pernyataan yang 
diadopsi dari penelitian sebelumnya yang dilakukan oleh Sugiyanto dan Febriana tahun 2016.

Teknik analisis data menggunakan uji Wilcoxon untuk menganalisis adanya pengaruh peer education terhadap minat WUS Melakukan IVA di Banjar Tegal Desa Kubutambahan Kabupaten Buleleng.

\section{HASIL}

Responden dalam penelitian ini adalah dikarakteristikan berdasarkan usia, pekerjaan, pendidikan terakhir, penghasilan, informasi terkait pemeriksaan IVA, percaya atau tidak mengalami kanker, dukungan keluarga dan suami. Karakteristik responden berdasarkan usia dapat dilihat selengkapnya pada tabel 1 .

Tabel 1. Karakteristik Responden Berdasarkan Usia

\begin{tabular}{lcccc}
\hline $\begin{array}{l}\text { Data } \\
\text { Sosiodemografi }\end{array}$ & Mean & Median & Min & Max \\
\hline Usia responden & 26,34 & 25 & 18 & 44 \\
\hline
\end{tabular}

Berdasarkan tabel 1 diketahui bahwa rata-rata usia responden adalah 25 tahun dengan usia paling muda adalah 18 tahun dan usia tertua adalah 44 tahun.

Karakteristik responden berdasarkan pekerjaan dapat dilihat selengkapnya pada tabel 2.

Tabel 2. Karakteristik Responden Berdasarkan Pekerjaan

\begin{tabular}{lcc}
\hline Data Sosiodemografi & Frekuensi (n) & Persentase (\%) \\
\hline Pekerjaan & & \\
Tidak bekerja/ IRT & 26 & 59.1 \\
PNS & 1 & 2.3 \\
Swasta & 11 & 25 \\
Wiraswasta & 5 & 11.3 \\
Petani & - & - \\
Pegawai BUMN & 1 & 2.3 \\
Total & 44 & 100 \\
\hline
\end{tabular}

Berdasarkan tabel 2 di atas dapat dilihat bahwa sebagian besar responden tidak bekerja atau sebagai Ibu rumah tangga yaitu sebanyak 26 orang atau sebesar 59,1\%.

Karakteristik responden berdasarkan pendidikan dapat dilihat selengkapnya pada tabel 3 . 
Tabel 3. Karakteristik Responden Berdasarkan Pendidikan

\begin{tabular}{lcc}
\hline $\begin{array}{l}\text { Data } \\
\text { Sosiodemografi }\end{array}$ & $\begin{array}{c}\text { Frekuensi } \\
(\mathrm{n})\end{array}$ & $\begin{array}{l}\text { Persentase } \\
(\%)\end{array}$ \\
\hline Pendidikan terakhir & & \\
Tidak sekolah & - & - \\
Lulus SD & - & - \\
Lulus SMP & 2 & 4.5 \\
Lulus SMA/SMK & 37 & 84.1 \\
Lulus PT & 5 & 11.4 \\
Total & 44 & 100 \\
& & \\
\hline
\end{tabular}

Berdasarkan tabel 3 di atas dapat dilihat bahwa sebagian besar responden berpendidikan terakhir SMA/SMK yaitu sebanyak 37 orang atau sebesar 84,1\%.

Karakteristik responden berdasarkan penghasilan perbulan dapat dilihat pada tabel 4.

Tabel 4. Karakteristik Responden Berdasarkan Penghasilan Perbulan

\begin{tabular}{lcc}
\hline Data Sosiodemografi & Frekuensi (n) & Persentase (\%) \\
\hline Penghasilan perbulan & & \\
$\leq 1.500 .000$ & 29 & 65.9 \\
$>1.500 .000$ & 15 & 34.1 \\
Total & 44 & 100 \\
\hline
\end{tabular}

Berdasarkan tabel 4 diatas bahwa rata-rata penghasilan Ibu perbulan adalah di bawah UMR (upah minimum regional) sebanyak 29 orang atau sebesar $65,9 \%$.

Karakteristik responden berdasarkan informasi terkait IVA sebelumnya dapat dilihat pada tabel 5 .

Tabel 5. Karakteristik Responden Berdasarkan Informasi Terkait IVA

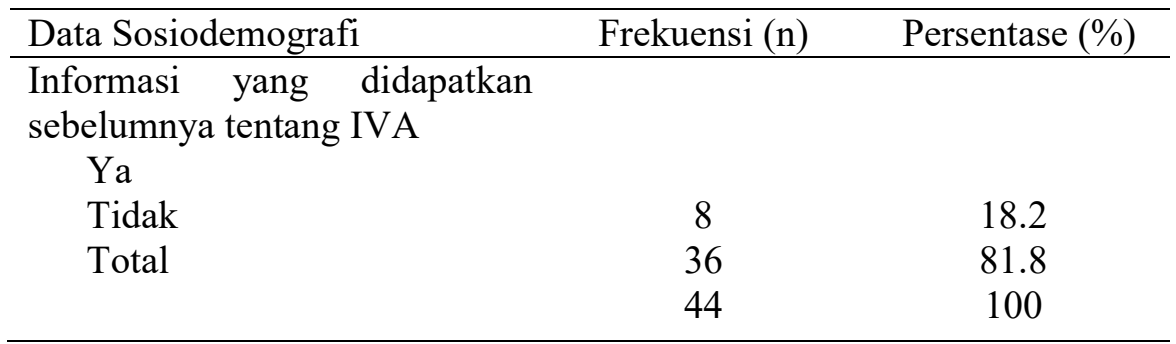

Berdasarkan tabel 5 di atas didapatkan bahwa sebagian besar responden belum pernah mengetahui informasi tentang IVA yaitu sebanyak 36 orang atau sebesar $81,8 \%$.

Karakteristik responden berdasarkan percaya tidak akan mengalami kanker serviks dapat dilihat pada tabel 6. 
Tabel 6. Karakteristik Responden Berdasarkan Percaya Tidak Akan Mengalami Kanker Serviks

\begin{tabular}{|c|c|c|}
\hline Data Sosiodemografi & Frekuensi (n) & Persentase $(\%)$ \\
\hline $\begin{array}{l}\text { Mungkin mengalami } \\
\text { serviks }\end{array}$ & & \\
\hline Tidak percaya & 10 & 22.7 \\
\hline Ragu-ragu & 28 & 63.6 \\
\hline Percaya & 6 & 13.6 \\
\hline Total & 44 & 100 \\
\hline
\end{tabular}

Berdasarkan tabel 6 di atas sebagian besar responden ragu-ragu jika mengalami kanker serviks sebanyak 28 orang atau sebesar $63,3 \%$.

Karakteristik responden berdasarkan dukungan suami, keluarga dan lingkungan sosial dapat dilihat pada tabel 7.

Tabel 7. Karakteristik Responden Berdasarkan Dukungan Suami, Keluarga dan Lingkungan Sosial.

\begin{tabular}{lcc}
\hline Data Sosiodemografi & Frekuensi (n) & Persentase (\%) \\
\hline Dukungan suami, keluarga, & & \\
lingkungan untuk periksa IVA & & \\
$\quad$ Ya & & \\
$\quad$ Tidak & 14 & 31.8 \\
Total & 30 & 68.2 \\
& 44 & 100 \\
\hline
\end{tabular}

Tabel 7 di atas menunjukkan sebagian besar responden tidak mendapat dukungan untuk pemeriksaan IVA yaitu sebanyak 30 orang atau sebesar $68,2 \%$.

Tabel 8. Hasil Analisis Data Bivariat Wilcoxon

\begin{tabular}{lc}
\hline \multicolumn{1}{c}{ Variabel } & p-value \\
\hline Minat pemeriksaan IVA pre peer & 0,001 \\
education -Minat pemeriksaan IVA & \\
post peer education & \\
\hline
\end{tabular}

Pada tabel 8 di atas menunjukkan bahwa terdapat perbedaan rata-rata minat pemeriksaan IVA sebelum diberikan peer education dibandingkan dengan minat pemeriksaan IVA setelah diberikan peer education memilik nilai p-value yaitu $0,001<0,05$. Sehingga dapat disimpulkan bahwa ada pengaruh pemberian peer education terhadap minat ibu untuk melakukan pemeriksaan IVA hal ini signifikan secara statistik dilihat dari nilai $\mathrm{p}<0,05$.

Hasil penelitian ini menunjukkan bahwa minat melakukan IVA sebelum diberikan peer education dengan kategori rendah sebanyak 24 orang $(54,5 \%)$, kategori sedang sebanyak 19 orang $(43,2 \%)$, tinggi 1 orang $(2,3 \%)$. 
Kemudian hasil yang menunjukkan bahwa minat melakukan IVA setelah peer education sebanyak 6 orang $(13,6 \%)$ dengan kategori tinggi, 33 orang (75\%) dengan kategori sedang dan 5 orang $(11,4 \%)$ dengan kategori rendah.

Dari hasil tersebut dapat disimpulkan bahwa minat melakukan IVA setelah peer education menjadi baik atau meningkat. Proporsi menunjukkan lebih dari setengah jumlah responden menunjukkan peningkatan minat melakukan IVA.

\section{PEMBAHASAN}

Berdasarkan uji Wilcoxon didapatkan nilai signifikan $\mathrm{p}=0,001(\mathrm{p}<\alpha)$. Hal ini dapat disimpulkan bahwa ada pengaruh peer education terhadap minat WUS melakukan IVA di Banjar Tegal Desa Kubutambahan Kabupaten Buleleng.

Minat adalah rasa lebih suka dan rasa ketertarikan pada suatu hal atau aktivitas, tanpa ada yang menyuruh. Minat pada dasarnya adalah penerimaan akan suatu hubungan antara diri sendiri dengan sesuatu di luar diri (Djaali, 2013). Faktor yang mempengaruhi minat salah satunya yaitu pendidikan kesehatan, kurangnya pengetahuan atau informasi menyebabkan rasa takut terhadap rasa sakit saat pemeriksaan, kerepotan, keraguan akan pentingnya pemeriksaan, takut terhadap kenyataan hasil pemeriksan sehingga minat yang muncul dalam pemeriksaan IVA rendah. Minat yang rendah muncul karena belum pahamnya WUS tentang pentingnya pemeriksaan IVA karena belum terpaparnya informasi melalui pendidikan kesehatan (Rahma dan Prabandari, 2013).

Pendidikan sebaya (peer education) menjadi metode pilihan dalam penyampaikan informasi karena pendidik sebaya menggunakan bahasa yang kurang lebih sama sehingga informasi yang disampaikan mudah dipahami oleh teman sebayanya. Teman sebaya juga mudah dalam mengemukakan pikiran dan perasaannya dihadapan pendidik sebaya sehingga pesan-pesan sensitif dapat disampaikan secara lebih terbuka dan santai (Yulizawati dkk, 2016). Menurut Rasyid (2009) salah satu aspek minat terdiri dari komponen, kognitif yaitu bagian dalam diri yang timbul berdasarkan pengetahuan atau pemahaman terhadap objek. Pendidikan kesehatan berupaya agar masyarakat mengetahui bagaimana cara memelihara kesehatan, menghindari dan mencegah hal-hal yang merugikan kesehatan mereka dan orang lain. Pendidikan kesehatan adalah suatu pendidikan yang dilakukan dengan cara menyebarkan pesan menanamkan keyakinan sehingga sadar, tahu dan mengerti, tetapi juga mau serta bisa melakukan suatu tindakan yang ada hubungannya dengan kesehatan (Ardhila dan Maliya, 2016).

Perubahan minat tidak terlepas dari meningkatnya pengetahuan seorang individu. Pengetahuan yang baik akan memberikan pandangan yang sesuai dan memperbaiki pandangan yang keliru mengenai suatu objek dan kondisi tertentu (Sugiyanto dan Febriana, 2016). Pada kondisi ini peer education memberikan pendidikan kesehatan untuk meningkatkan pengetahuan WUS sehingga diharapkan sikap sebagai cerminan minat pemeriksaan IVA dapat meningkat (Andari dkk, 2014).

Menurut Asdar, dkk (2015) pendidikan teman sebaya (peer education) merupakan sebuah strategi pendidikan kesehatan dengan memanfaatkan peran teman sebaya untuk berbagi informasi sehingga terjadi perubahan perilaku kepada teman sebaya dalam kelompoknya (peer group). 
Peer education merupakan salah satu metode yang paling efektif dalam menangani masalah di bidang kesehatan karena sifatnya yang fleksibel dan menciptakan adanya komunikasi yang aktif antar individu dalam prosesnya. Proses peer education memberikan manfaat baik pada peer educator dalam hal peningkatan kemampuan dalam komunikasi, perencanaan, mengkoordinir, kepercayaan diri dan sikap asertif yang dapat dikembangkan untuk membantu menyebarkan informasi mengenai suatu topik. Peer education efektif dalam meningkatkan minat WUS untuk melakukan pemeriksaan IVA karena ditemukan adanya peer support yaitu dukungan dalam kelompok untuk saling mempengaruhi untuk melakukan pemeriksaan IVA, sehingga dalam kelompok terjadi interaksi saling memberi dan menerima informasi mengenai kanker serviks dan pemeriksaan IVA. Proses inilah yang secara alami bersumber dari kelompok akan mempengaruhi kelompok dan membentuk minat untuk melakukan pemeriksaan IVA dari WUS (Wardhani dkk, 2018).

Interaksi pada proses pendidikan kesehatan secara konvensional hanya terjalin antar narasumber dan peserta, tetapi pada peer education proses interaksi berjalan secara dinamis, sehingga terjadi proses berbagi pengalaman antar anggota kelompok yang saling bertukar informasi terkait deteksi dini kanker serviks yang telah mereka miliki (Mbachu et.al, 2016). Proses bertukar pengalaman ini akan memberikan kesan menguatkan terhadap satu sama lain untuk melakukan pemeriksaan IVA.

Penelitian senada juga dilakukan di Nigeria bagian Tenggara menemukan adanya pengaruh positif pemberian peer education terhadap perubahan persepsi terhadap kesehatan dan pemeriksaan diri terhadap kanker serviks pada WUS di Nigeria bagian Tenggara, dimana $6,8 \%$ wanita yang ikut serta di dalam penelitian sadar mengenai tindakan pencegahan dengan sadar melakukan pemeriksaan diri (Mbachu et.al, 2017).

Hasil ini didukung oleh penelitian yang dilakukan oleh Follona dengan judul "Perbedaan Pendidikan Kelompok Sebaya Tentang Pendewasaan Usia Perkawinan di Perkotaan dan Pedesaan" pada tahun 2014 di Bogor, pelaksanaan peer education berlangsung selama 60-90 menit, tiga kali selama dua minggu dengan menggunakan metode diskusi kelompok dan alat bantu berupa modul yang telah disiapkan oleh peneliti, menunjukkan bahwa pendidikan sebaya dapat meningkatkan pengetahuan dan sikap remaja perkotaan serta pedesaan dengan $\mathrm{p}<$ 0,001 .

Peer education efektif dalam meningkatkan minat WUS untuk melakukan pemeriksaan IVA karena ditemukan adanya peer support yaitu dukungan dalam kelompok untuk saling mempengaruhi untuk melakukan pemeriksaan IVA, sehingga dalam kelompok terjadi interaksi saling memberi dan menerima informasi mengenai kanker serviks dan pemeriksaan IVA. Proses inilah yang secara alami bersumber dari kelompok akan mempengaruhi kelompok dan membentuk minat untuk melakukan pemeriksaan IVA dari WUS (Wardhani dkk, 2018).

\section{SIMPULAN}

Berdasarkan hasil penelitian dan pembahasan dapat diambil simpulan bahwa minat melakukan IVA pada saat pre-test sebagian besar responden mempunyai minat pada kategori rendah sebanyak 24 orang $(54,5 \%)$, kategori sedang sebanyak 
19 orang $(43,2 \%)$, tinggi 1 orang (2,3\%). Minat melakukan IVA pada saat post-test sebagain besar mempunyai minat tinggi sebanyak 6 orang $(13,6 \%), 33$ orang $(75 \%)$ dengan kategori sedang dan 5 orang $(11,4 \%)$ dengan kategori rendah. Terdapat pengaruh peer education terhadap minat WUS melakukan IVA di Banjar Tegal Desa Kubutambahan Kabupaten Buleleng, hal ini ditunjukkan dengan nilai signifikan $p=0,001(p<0,05)$.

\section{SARAN}

Saran bagi responden penelitian, diharapkan WUS di Banjar Tegal Desa Kubutambahan dapat menerapkan pemeriksaan IVA secara berkala atau rutin dan dapat menyebarluaskan informasi yang didapat dari kegiatan peer education terkait kanker serviks dan pemeriksaan IVA kepada masyarakat.

Bagi Kepala Puskesmas, diharapkan peer education dapat dijadikan salah satu program dalam pemeberian informasi mengenai kanker serviks dan pemeriksaan IVA di komunitas untuk meningkatkan minat pemeriksaan IVA.

Bagi peneliti selanjutnya, agar membandingkan metode peer education dengan metode lain yang lebih menarik yang dapat meningkatkan minat WUS melakukan pemeriksaan IVA.

\section{DAFTAR PUSTAKA}

American Cancer Society. 2014. Guide to Controlling Cancer Pain. Available at: http://www.cancer.org/acs/groups/cid/documents/webcontent/002906pdf.pdf. (8 Maret 2018).

Ardhila, N., dan Maliya, A. 2016. Pengaruh pendidikan kesehatan tentang inspeksi visual asam asetat test terhadap pengetahuan dalam pencegahan kanker serviks di desa Godekan Mojolaban Surakarta. Universitas Muhammadiyah Surakarta.

Asdar, M., Thaha, I. L. M. dan Nasir, S. 2015. Intervensi Pendidikan Sebaya Dalam Meningkatkan Remaja di Kabupaten Pangkep. Jurnal: MKMI, pp. 59-67.

Dewi, L., Suryani, N. dan Murdani, P. 2013. Pengetahuan dan Sikap Wanita Usia Subur (WUS) dengan Pemeriksaan Inspeksi Visual Asam Asetat (IVA) di Puskesmas Buleleng I. Jurnal: Pendidikan Kesehatan. Available at: http://jurnal.pasca.uns.ac.id/index.php/pdpk/article/download/229/217 Februari 2018).

Dinas Kesehatan Provinsi Bali. 2015. Profil Kesehatan Provinsi Bali Tahun 2014. Available at: http : //www.diskes.baliprov.go.id. ( 15 Februari 2018). . 2017. Data Survailens Terpadu Penyakit. Available at: http : //www.diskes.baliprov.go.id. ( 17 Februari 2018).

Djaali .2013. Psikologi Pendidikan. Jakarta: Bumi Aksara.

Dwika, G., YI, D. dan Sri, N. 2014. Faktor-faktor yang berhubungan dengan perilaku Pencegahan kanker serviks pada wanita usia subur. Jurnal Online Mahasiswa (JOM). Available at: http://jom.unri.ac.id/index.php/JOMPSIK/article/view/3432 (10 Februari 2018).

Follona, W., Raksanagara, A.S dan Purwara, B.H. 2014. Perbedaan pendidikan kelompok sebaya tentang pendewasaan usia perkawinan di perkotaan dan 
pedesaan. Jurna Kesehatan Masyarakat Nasional, Vol. 9, No. 2, pp. 157-163. Irianto, K. 2014. Epidemiologi Penyakit Menular dan Tidak Menular Panduan Klinis. Bandung: Alfabeta.

Kemenkes RI. 2016. Ratusan Pegawai Perempuan Kemenkes Lakukan Deteksi Dini Kanker Majalah Kementerian Kesehatan RI Bulan November. Available : http://spiritia.or.id. (14 Maret 2018).

Marliana, Y. 2014. Akurasi Metode Inspkesi Visual Dengan Asam Asetat/IVA Untuk Deteksi Dini Kanker Leher Rahim. Jurnal Kesehatan Prima, vol.8 no.2, pp. 1336-1344.

Mbachu, C., Dim, C. dan Ezeoke, U. 2017. Effects of peer health education on perception and practice of screening for cervical cancer among urban residential women in south-east Nigeria: A before and after study. BMC Women's Health. Jurnal: BMC Women's Health, Vol 17, No. 1, pp. 1-8.

Rahma, Rina, A., dan Prabandari, F. 2013. Beberapa faktor yang mempengaruhi minat wus (wanita usia subur) dalam melakukan pemeriksaan IVA (inspeksi visual dengan pulasan asam asetat) di Desa Pangebatan Kecamatan Karanglewas Kabupaten Banyumas tahun 2011. Jurnal Bidan Prada, 3(01).

Rasyid. 2009. Penilaian Hasil Belajar. Bandung: Wacana Prima

Riskesdas. 2013. Badan Penelitian dan Pengembangan Kesehatan, Departemen Kesehatan Republik Indonesia. Jakarta

Sugiyanto dan Febriana, T. N. 2016. Pengaruh Pendidikan Kesehatan Tentang Kanker Kerviks Terhadap Minat Pemeriksaan IVA Pada Kelompok Ibu Pengajian. Jurnal : Kebidanan dan Keperawatan, Vol. 12, No. 2, pp. 158-162.

Wardhani, G. K., Mudigdo, A., dan Qadrijati, I. 2018. Path analysis on the Determinants of Pap Smear Utilization for Cervical Cancer Early Detection in Women of Reproductive Age. Journal of Health Promotion and Behavior, 2(4), 359-370

Yulizawati, Sinta, L. E., Nurdiyan, A., Insani, A. A. 2016. Pengaruh Pendidikan Kesehatan Metode Peer Education Mengenai Skrining Terhadap Pengetahuan Dan Sikap Wanita Usia Subur Di Wilayah Kabupaten Agam Tahun 2016. Padang. FK UNAND 